\title{
MIARA ZIEMI. ZIEMSKA MIARA
}

Arkadiusz Gór n is i e w i cz, Wojna inomos. Carl Schmitt o problemie porzadku światowego, Universitas, Kraków 2019, ss. 232.

Osobom w Polsce zajmującym się oraz zainteresowanym dorobkiem naukowym Carla Schmitta przybyła nowa, ciekawa lektura, i to rodzimego autora. Jest nią książka krakowskiego politologa - Arkadiusza Górnisiewicza. Choć tłumaczeń klasycznych prac niemieckiego filozofa państwa i prawa w naszym kraju przybywa, to jednak mało kto w Polsce zajmował się dotąd, bliższymi nam może, poglądami Carla Schmitta $z$ okresu powojennego, a więc związanymi m.in. $z$ tzw. Grossraum, teoria partyzanta, prawem międzynarodowym regulującym kwestie wojny i państwa, a zwłaszcza $z$ koncepcją współczesnego nomos przedstawiona w obszernej monografii z 1950 roku Nomos der Erde im Volkerrecht des Jus Publicum Europeum (udostępnionej polskiemu czytelnikowi w tłumaczeniu Kingi Wudarskiej pod tytułem Nomos ziemi $w$ prawie międzynarodowym ius publicum europeum, 2019, staraniem zasłużonej Biblioteki Kwartalnika Kronos i Fundacji hr. Augusta Cieszkowskiego).

Tę dotychczas istniejącą lukę w polskiej recepcji poglądów autora Der Begriff des Politischen wypełnia właśnie praca Arkadiusza Górnisiewicza. I to, podkreślmy od razu, wypełnia w sposób intelektualnie satysfakcjonujacy, w pełni udany. Mamy bowiem do czynienia $z$ rozprawą rzeczową i treściwa - co nie jest wcale częste, esencjonalna, a zarazem przekrojowa. Zwięzła i treściwa, a jednak obejmująca wiele ważnych wątków $z$ powojennego dorobku filozofa $z$ Plettenbergu. Wojna i nomos znakomicie wprowadza w cała zawiła problematykę powojennego świata, tak jak go widzi Carl Schmitt. Górnisiewicz, posiadając dużą kulturę słowa, pisze ze swada, w sposób budzący zainteresowanie. Prezentuje $z$ dużą dokładnością dobrze dobrane 
zagadnienia, także $z$ bogatej literatury opracowań, dociera do ważnych tekstów, wydobywa $z$ nich istotne kwestie. Młodemu (jak na humanistę) krakowskiemu uczonemu można już teraz pozazdrościć oczytania, erudycji i zdolności łączenia poznanych myśli, poglądów, stanowisk - wśród których porusza się ze znawstwem i swobodnie w wyczerpujace tematyczne całości.

Ale, aby zachęcić do lektury książki Arkadiusza Górnisiewicza, przyjrzyjmy się także i samemu meritum sprawy, o której ona traktuje. Wojna, ta szczególna, w XX wieku, to zjawisko opisywane wielokrotnie i wielorako. Ale tu jest ona przedmiotem teoretycznej, a nawet historiozoficznej refleksji. Jako mało znane natomiast jawi się pojęcie nomos. Jest ono podobne do kilku innych, charakterystycznych dla czasów bardzo odległych, dla zamierzchłej wręcz przeszłości, ukazujących jej swoistość, niezwykłość, o której niewiele wiemy, a jeśli nawet wiemy, to zbyt łatwo to zapominamy. Przeszłość ta skłania do pokonujących dystans czasowy porównań $z$ dniem nam współczesnym, a zwłaszcza skłania do refleksji nad wyraźnie na jej tle widoczna wyjatkowościa naszego wieku - „wieku skrajności”. Podobne do nomos sa bowiem ethos, jus, tora, a także maat. (Warto dodać, że to ostatnie pojęcie przybliża np. praca pt. Maat. Sprawiedliwość i nieśmiertelność $w$ starożytnym Egipcie, znanego egiptologa Jana Assmanna, wydana w Polsce w 2016 roku). We wszystkich tych przypadkach chodzi o coś, co nie ma współcześnie odpowiednika, o wspólne konkretnej dawnej społeczności (Gemeinschaft - wspólnocie, a jeszcze nie Gesellschaft - społeczeństwu) prawa, ale zarazem też prawdy, tradycje, obyczaje, treści zarazem religijne i egzystencjalne, moralne i filozoficzne - cały ich swoisty kompleks. Chodzi o prawo zakorzenione w całościowym obrazie świata, w kontekście ....ducha obiektywnego danej wspólnoty, o to zatem, co nieoddzielalne od niej, określające jej tożsamość. Różne już od tego były skonkretyzowane w wielorakich elementach szerokiej przestrzeni religijnej, politycznej, kulturowej znaczenia średniowiecznej Christianitas, choć jednak to do pozostałości takiego właśnie ducha dawnych praw zalecał docierać, wydobywać i opisywać je Charles Louis Montesquieu.

U Schmitta pojęcie nomos, bardzo bliskie wyróżnianej przez niego odmianie konstytucji - konstytucji absolutnej, przecina się $z$ innym pojęciem, $z$ pojęciem miary, miary dającej zakorzenienie, a czerpanej $z$ czegoś na wskroś realnego, $z$ określonego obszaru zbiorowego życia (Land und Meer), przecina się także ze szczególnym rodzajem prawa i myślenia prawniczego, które Schmitt nazywa Ordodenken. 
Poza tymi jest jeszcze jedno wyraźne ukierunkowanie jego myślenia polemiczne, będące w opozycji do teorii prawa, ale właściwie też teorii nowoczesności, która prezentuje jego stały adwersarz - Hans Kelsen. Wbrew Kelsenowskiemu radykalnemu i stanowczemu oddzieleniu sollen (prawa) od sein (państwa, władzy, polityki) Schmitt pokazuje i tłumaczy możliwe złączenie, możliwy zwiąek tych elementów.

Carl Schmitt jest konserwatystą nie tylko dlatego, że ma świadomość grzechu pierworodnego i uznaje autorytet Kościoła, zwłaszcza w dawnym jego rycie, ale i dlatego, że dziejowe instytucje i struktury nie sa dla niego tylko przyobleczonymi w historyczny kostium ideami ani racjonalistycznymi, ani romantycznymi. Nie są też wynikiem dziejowego procesu alienacji Mają one - konkretny podmiot polityczny, suwerenna władza, pozytywne prawo - swoją obiektywna poniekąd treść, swoje autonomiczne znaczenie, które trzeba rozpoznać i wziąć pod uwage.

Schmitt stara się odsłonić miarę ziemi, szuka w ten sposób ratunku przed powojennym chaosem oderwanych idei, interesów, ambicji i namiętności, chaosem, który gęstnieje, w którym Europa się pogrąża. Szuka zakorzenienia dla woli, życia, działania, dla prawd ogólnych o zbiorowej egzystencji, która w XX wieku uległa tak katastrofalnej destrukcji. W nowych kategoriach ukazuje ludzkie dzieje. To bardzo ciekawe, że w kategoriach dynamicznych: nehmen, teilen, weiden. Oto sa, powiada, trzy podstawowe formy ludzkiego bycia, bycia grup ludzkich, bycia w świecie - na ziemi. Ważny jest ich układ, kolejność, porządek. Niegdyś pierwszym było nehmen (które wcale nie oznacza tylko prymitywnego zaboru, podboju, bo sens walki, działania przemoca, zdobywania zmienia się w dziejach, inny jest, gdy dokonuje się go podług własnych, ograniczonych sił, inny zaś, gdy ma się do dyspozycji wszelkie, nieograniczone wręcz, techniczne środki po temu). Dziś może porządek ten się zmienia i inne aktywności, co znamienne, spośród tych trzech, stają się pierwsze.

Górnisiewicz omawia kolejno kluczowe zagadnienia, m.in. rewolucję przestrzeni, specyfikę lądu i morza jako obszarów politycznej egzystencji, pisze o wojnie sprawiedliwej i wojnie totalnej, o formach anglosaskiego imperializmu i tej szczególnej formie angielskiej „państwowości" - morskiej państwowości.

W tej tak zawiłej materii, która stanowi rzeczywistość polityczna i prawna mająca u Schmitta wiele ontologicznych poziomów, autor pracy Wojna i nomos próbuje odkryć systematyczność poglądów plettenberskiego myśliciela - powojennego intelektualnego outsidera. 
To wielkie zadanie. Wielu znakomitych interpretatorów dzieła Schmitta: Hofmann, Quaritsch, także Maschke i Waldstein, wszyscy oni stawiali to pytanie. Arkadiusz Górnisiewicz także stara się na nie odpowiedzieć. Czy udało mu się to w pełni, całkowicie? Niech na to pytanie, po lekturze, każdy czytelnik odpowie $z$ osobna i po swojemu - wedle własnych kryteriów.

Systematyczność poglądów to bardzo ważny problem u myśliciela analizującego meandry „konkretnego życia” w XX wieku. Ale jeśli nawet systematyczności tej nie można by było wykazać, to może dlatego, że wiek ten, wiek totalitaryzmów i totalnych wojen swiatowych, jest zbyt tragiczny, mroczny, wyjątkowy, aby można dlań znaleźć miarę. Pozostaje więc systematyczność ... podejmowanego wysiłku znalezienia jej.

Może zresztą na tle wielorakich intelektualnych zmagań z czasem autora Land und Meer inaczej: pełniej, wyraźniej, dobitniej jawi się wielkość dokonań polskich myślicieli - analityków XX wieku: Aleksandra Wata, Józefa Mackiewicza, Józefa Czapskiego, Czesława Miłosza... . Oni wiedzieli, że mają do czynienia $z$ taka rzeczywistością ..., o której nie śniło się filozofom, zwłaszcza niemieckim, i dlatego żadne poszukiwane abstrakcyjne formuły rozumu ani teoretyczne rozprawy jej treści nie wyczerpią.

Paweł Kaczorowski Uniwersytet Kardynała Stefana Wyszyńskiego ORCID: 0000-0001-7461-3959 p.kaczorowski@uksw.edu.pl 